\title{
International marketing and economic diplomacy
}

\author{
Khalid Aldeeb
}

Phd, candidate

DOI: 10.29322/IJSRP.11.10.2021.p11883

http://dx.doi.org/10.29322/IJSRP.11.10.2021.p11883

\begin{abstract}
Marketing organization today, deals with activities such as decision making in all marketing areas, concerning products, marketing channels, pricing, physical distribution and promotion. They establish relationships between employees in the marketing sector and professionals who are responsible for making marketing decisions and planning that are key to the success of any business firm. Hence, we can say that the marketing organization is an organizational structure that implements company policies, helps in making decisions regarding production, packaging, price, advertising, promotion, sales, brand, trademark and distribution channels, etc.
\end{abstract}

Index Terms- Marketing strategies, economic diplomacy, markets, brend.

\section{INTRODUCTION}

$\mathrm{I}^{\mathrm{n}}$ technological arena, modern marketing activities are consumer-oriented. So, in order to survive in a competitive market, organizations need to hire marketing organizations, which can make a decision about marketing factors, ie. product, price, promotions, etc. in order to satisfy the needs and desires of customers and maximize the profit of the organization that hired them.

Therefore, a healthy marketing organization is a pillar of success for any business and provides a framework for establishing authority among subordinates, locating responsibilities, establishing sales routines, conducting proper sales force monitoring, avoiding duplication of duty, and allowing senior executives to devote more time planning policy issues.

\section{PRINCIPLES APPLIED By MARKETING ORGANIZATIONS}

Usually, principles applied by marketing organizations are: -Unity of objectivity - Achieving goals is the main purpose of organizing. The organization and every part of it should be focused on achieving goals. Each member of the organization should be familiar with the common goals. Therefore, organizational goals, departmental goals, and individual goals must be clearly defined.

- Efficiency - An organization is efficient if it is able to achieve predetermined goals at the lowest possible cost. The organization must also provide the maximum possible satisfaction to its employees and should also contribute to the well-being of the community.

- Division of labor - For a healthy and efficient organization, the overall task should be divided in such a way that the work of each individual in the organization is limited and the work should be assigned to the right person according to his physical, mental and psychological abilities.

- Range of control - Due to time and ability constraints, no CEO can effectively oversee more than a certain number of subordinates. Therefore, each executive should be required to supervise a reasonable number of managers depending on his ability, job, complexity of duties of his subordinates, nature and importance of the job to be supervised, etc.

- Scalar principle - It is sometimes known as a chain command. According to the principle, authority and responsibility should be in a clear line from the top to the bottom of the organization. The clearer the line of government in the company, the more efficient the communication and responsible decisionmaking will be.

- Delegation - The authority delegated to an individual manager should be adequate to enable him to achieve the results expected of him.

- Functional definition - The duties, responsibilities, authorities and organizational relationships of an individual working in a particular position should be clearly defined to avoid confusion. Clearly defined duties and powers of the individual will contribute to more efficient achievement of goals.

- Authority and responsibility - It is a tool with which the manager is able to create an environment for individual performance. Therefore, the authority and responsibility of each manager and supervisor should be clearly defined. Every manager should be responsible for the actions of his subordinates as well as for his own actions.

- Unity of command - Subordinates should receive orders from only one superior. This principle makes it possible to avoid confusion, disorder and indiscipline. Thus, this principle creates a sense of personal responsibility and avoids the problems of conflict.

- Unity of direction - For an organization to be healthy and efficient, there must be one manager and one plan for a group of activities aimed at the same goals.

- Coordination - There must be an orderly schedule of group efforts and unity of action and coordination of activities at different levels.

- Flexibility - The organizational structure should be flexible so that it can be easily adapted to changing conditions. The organizational structure should allow for expansions, mergers and replacements, etc. Without compromising the basic design.

- Continuity - The organization should be structured so that it has continuity of work.

- Communication - Effective communication is necessary for a healthy and efficient organization. It is the process of 
transforming information from one person to another at different levels. It includes a systematic and continuous process of communication, listening and understanding the opinions, ideas, feelings, information of employees in the organization.

- Simplicity - For better communication and coordination, the levels of the organization should be as low as possible. This principle focuses on the simplicity of the organizational structure.

\section{IMPORTANCE OF MARKETING ORGANIZATIONS}

It is multiple, and can contribute to the success of the company in the following ways:

- Facilitates administration - The organization provides a framework within which coordination and control functions can be performed effectively. Increases managerial efficiency, avoids delays and duplication of work, motivates employees, etc. It provides a system of authority and a network for effective communication.

- Optimal use of resources and new technologies - In a business enterprise, optimal use of technological improvements can achieve a more efficient structure of the organization. In addition, a healthy organization enables optimal use of human resources and ensures that each individual is placed in the job for which he or she is most suitable.

- Helps the growth of the company - A healthy organization enables the growth of the company. Systematic division of labor and delegation of authority enable the commencement of new activities and the satisfaction of public market demands.

- Facilitates coordination - A healthy organization assigns the right job to the right person, improves job satisfaction and interpersonal relationships. A well-defined job and a clear boundary of authority and responsibility help to establish cordial relationships between different departments or divisions of the company. Division of labor, better use of technology and human talents, etc. They help improve efficiency and quality of work.

- Encourages creativity and innovation - A well-designed organization stimulates creative thinking and initiative of employees. Provides efficient change management and responds favorably to changes in the environment.

\section{MARKETING STRATEGIES}

In order for a modern organization to be able to achieve its goals, the marketing manager needs to further divide the goals set before the marketing strategy into primary and secondary. "They are primary in the domain of increasing the level of sales, generating total consumption on the market, ie generating the socalled primary demand. Market penetration, geographical and expansion of sales by product lines are defined as secondary marketing goals, but also the development of new products,

1 Wilson, R., Gilligan, C. (2005). Strategic Marketing Management - Planning, Implementation\&Control. Amsterdam: Elsevier, p. 273

${ }^{2}$ McDonald, M., Mouncey, P. (2009). Marketing Accountability How to measure marketing effectiveness. London: Kogan Page, p. 75

This publication is licensed under Creative Commons Attribution CC BY. http://dx.doi.org/10.29322/IJSRP.11.10.2021.p11883 increasing awareness of the individual brand in the brand portfolio, increasing profitability in working with individual distribution channels, etc." ${ }^{1}$ If the goals are to be achieved, marketing managers must shape the marketing strategy into a concrete plan of activities.

The strategic activities that make up a marketing strategy are: - "understanding the market - defining target business segments and - defining value proposals. "2

Understanding the market starts from the assumption that the understanding of consumers in relation to competing organizations is the basis for formulating a marketing strategy as a way to achieve success in the market. Better market segmentation as well as giving added value in relation to the competition will be achieved by understanding the motives of consumers, the way they buy, their characteristics and the like. "In addition to a deep understanding of customers, marketing managers must, together with scientific principles, use creativity or skill to define an appropriate value proposition, based on that understanding, ie to adequately communicate value. In line with that is the definition of marketing management as an art and science of choosing target markets, obtaining, maintaining and improving relationships with consumers through the creation, delivery and communication of superior value. "3

Defining target business segments is another element of marketing strategy. The basis for defining the objectives of the lending segment is to understand customer needs. The market segment includes a group of consumers who have similar needs and who are different from those in other parts of the market. Kotler presented an explanation that "the hierarchy of importance of individual product attributes to customers can reveal market segments. Some customers will prefer a low price above all else, so they can be segmented by price, those who decide by product type, e.g. car type (convertible, sedan, etc.) can be segmented by product type, some prefer the brand and can be segmented into those for whom the brand is important due to psychological differentiation from other consumers, some can be segmented by supporting services that are important to them, etc. It is also possible to combine several basics of segmentation. "4

"The final choice of target segments within the marketing strategy is ultimately reduced to the following options:

a) targeting the entire market instead of individual segments with the application of one combination of marketing mix - the socalled. undifferentiated marketing,

b) differentiated marketing, in which the company has selected several target segments and uses a different combination of marketing mix for each, and

c) concentrated marketing, when one marketing mix is applied to all target segments. "5

${ }^{3}$ Kotler, P., Keller, K. (2006). Marketing Management. Upper Saddle River, New Jersey: Pearson Prentice Hall, twelfth edition, p. 5

${ }^{4}$ Kotler, P. (2003). Marketing Management. Upple Saddle River, New Jersey: Prentice Hall, eleventh edition, p. 286

5 Filipović, V., Kostić-Stanković, M. (2009). Marketing management. Belgrade: FON-Institute of Management, page 46 
Defining a value proposition is the last element of a marketing strategy. Within this part of the marketing strategy, the value takes the form that the company offers to the consumer (in the form of a marketing mix). "As with other functions in the company, after defining the marketing strategy as a functional strategy, it is necessary to make a marketing work plan. Correspondent plans for other functions are the plan of production, procurement, human resources, etc. In this way, the process shown in the previous figure is completed, by formulating a marketing plan based on the marketing strategy. The work plan of each function includes a number of programs, projects and activities that need to be done in order to implement a functional strategy. The marketing plan lists the necessary programs, promotional campaigns, various types of projects and activities in order to implement the marketing strategy. It is necessary to emphasize that the solutions generated by the marketing strategy and marketing plan must be designed to be cost-effective, in order to achieve the highest possible financial result. One of the ways to measure this efficiency can be expressed by the following formula:

\section{Marketing efficiency = marketing / sales costs $" 6$}

"Results of a marketing strategy are of particular importance. Two of them are extremely important - satisfaction and loyalty, which together generate market share as the end result. U.S. consumer satisfaction surveys have found that companies with a satisfaction index in the top $50 \%$ create 2.4 times higher value for shareholders than companies in the bottom $50 \%$ of the value of this index."

Customer satisfaction is closely related to the attributes of the product that generate it, to the accompanying services or to the psychological differentiation associated with the brand. In conditions of intense competition, new products, accompanying services are often created, or the meaning of the brand is innovated precisely in order to provide a higher level of satisfaction in relation to competitors.

\section{The role of marketing in creating a strategy of economic diplomacy}

The role of marketing in creating the image of cities, regions, nations, states is attracting increasing attention of sociologists, geographers, political scientists, economists, scientists and business people. "Rapid interest in this area of research creates a number of challenges. The modern scientific and professional position of "nation branding" has developed from destination branding to emphasize the uniqueness of a tourist destination. "8

"People generally know little about individual nations, and what little they know is formed on the basis of attitudes based on myths, rumors, anecdotes or on celebrities, athletes, actors, writers from those countries." 9

6 Filipović, V., Kostić-Stanković, M. (2009). Marketing management. Belgrade: FON-Institute of Management, page 308

${ }^{7}$ Milisavljević, M. (2004). Strategic marketing. Belgrade: Faculty of Economics, Center for Publishing, page 158

8 Vukić, F. (2009): Brand is an identity system, Acta Turistica Nova. Zagreb, pages 279-298.

${ }^{9}$ Dašić, D. (2013): Branding of States and Nations, Culture, no. 139 , p. 396-415.

This publication is licensed under Creative Commons Attribution CC BY

http://dx.doi.org/10.29322/IJSRP.11.10.2021.p11883
Due to the above, marketing activities aimed at creating the most positive image of a nation, takes on increasing influence in shaping the strategy of international diplomacy. Creating an adequate marketing strategy for one's own country is a very complex business, which today has universal proportions.

"Branding a country implies visual communication and application of marketing techniques in order to promote one country in the right way. The national brand includes numerous elements such as individual services and production brands, public institutions, elements of culture, art, science, sports, natural and anthropogenic resources, events, people, architecture, cultural and historical monuments, artistic creativity, information and ideas, etc. . The national brand includes all those elements that can improve the positive image of Serbia by differentiating it from others. " 10

"While in some countries they believe that their international reputation is lagging behind rapid economic and political development, elsewhere they think that their negative image is undeserved and that it hinders further social progress. Others believe that they are not recognizable enough, and that coming out of anonymity would enable more efficient participation in the global market. "11

"The national brand does not offer any tangible product or service, but represents and consists of various factors and elements: places - geographical locations, natural resources and tourist attractions, people - races, ethnic groups, hospitality, celebrities, history and historical places, culture and language, political and economic systems, social institutions, infrastructure and image. "12

When creating the image and identity of the state, we start from four perspectives that characterize the dimensions of the brand:

- $\quad$ "Brand as a product - The product and what makes it is a key element of brand identity. The brand associations that will develop when communicating with consumers depend on tangible and intangible attributes or product characteristics and the way consumers connect with them. The brand as a product contains several subdimensions, e.g. the goal of creating associations with a certain category can be related to a certain country or region,

- Brand as an organization - focuses on the attributes of the organization (created by employees, culture, values and programs of the company) instead of the attributes of the product or service. Examples of organizational attributes are e.g. innovation, consumer care, etc. Organizational attributes contribute to the formation of the so-called. brand value proposition and are more resistant to competition more than production attributes,

10 Bjeljac Ž., Terzić, A., Lović, S. (2015): Intangible cultural heritage of Serbia as a tourist brand, Tourist Business, No. 15, p. 53-61..

11 Manić, Lj., Simeunović-Bajić, N., Aleksić, M. (2012): Studentska percepcija uloge kulture i kulturnog nasledja u formiranju nacionalnog brenda, Kultura, br. 137. p. 194-209.

12 Fan, Y. (2006): Branding the Nation: What Is Being Branded? Journal of Vacation Marketing, Vol. 12, no. 1, p. 5-14. 
- Brand as a person / personality - this perspective is an extremely important dimension of identity, plays a key role in differentiating the brand, can be the basis for creating a relationship between consumer and brand,

- Brand as a symbol - this perspective provides cohesion and identity structure. A symbol is everything that represents a brand (visual symbol, metaphor and heritage, etc.). They play a big role in characterizing the brand. "13

Image that country has in the eyes of the world public is extremely important in international relations. In the midst of market competition, imposed by globalization, countries are forced to compete with each other for the attention and trust of investors, tourists, consumers, the media and more. That is why a positive image of a country is essential for the formation of a competitive advantage. There are seven steps in creating an effective marketing strategy to strengthen economic diplomacy:

1. "Create a working group with representatives of the state, arts, education, industry and media in order to launch a state branding program,

2. Investigate how the nation is perceived in the country itself, and also abroad,

3. Develop a discussion between various groups, with the aim of reviewing their own strengths and weaknesses in order to find the best way to brand the state,

4. Create one main idea in the positions of professional advisors, which must be unique and strong, based on the best qualities of the nation,

5. Build a brand book, define unified moves of visual communication of the state,

6. Adapt the messages for tourism, investment and export and integrate these messages into one whole so that they are suitable for the public,

7. Promote a system of interconnections between all actors in the nation's branding. "14

A strong and recognizable image of a state, nation, region, individual is the result of long-term activities. "For this reason, it is not as easy to copy the image as many activities from the marketing mix can be copied. The visitor replaces the information he receives from objective sources with subjective observations related to his personal characteristics. The image must be good, convincing, simple, recognizable and attractive. "15

\section{CONCLUSION}

Image of an individual person, group, organization, international company, region, state, etc., is created by their past, present and future actions, which in the consciousness of the diverse public create a certain perception of them. Based on that perception, the public forms their opinions and attitudes over time. A positive image or reputation of any individual, group, organization, which provides a long-term competitive advantage in the market, is the result of adequate and successful systematic management of all business activities. Such a long-term strategic process of managing business activities is based on a continuous commitment to improving the competitive position, creating a recognizable and attractive image, which should ultimately lead to the formation of a positive reputation.

One of the most important roles in creating a reputation is achieved through marketing activities. The main task of marketing strategy is to transform the identity into the desired perception in the public, and to adapt the strategic position and vision to the needs, attitudes and opinions of consumers or other public. Adopting the marketing concept of the new age and a holistic approach to marketing activities, enables the creation of a good reputation. Such management of marketing activities and business process, results in a positive attitude of the public, as well as harmonization of business social goals.

\section{AUTHORS}

First Author - Khalid Aldeeb Phd, candidate

\footnotetext{
13 Aeker, D.A. (2002): Building Strong Brands, Simon\&Schuster, London, p. 68

${ }^{14}$ Olins, W. (1999): Trading Identites, The Foreign Policy Centre,

15 Kotler, P., Haider, D.H. Rein, I. (1993): Marketing Places: Attracting Investment, Industry, and Tourism to Cities, States, and Nations, Simon \& Schuster, New York.
} London, p. 74. 